\title{
HOW TO COPE WITH HEAT AND COMBINED WITH HOT AND DRY CLIMATE IN CHAHAR- SOFE (FOUR-SIDED) HOUSES OF THE ZOROASTRIAN VILLAGE OF MAZRAEH KALANTAR, YAZD, IRAN
}

\author{
A. Farzaneh $1, *$ \\ ${ }^{1}$ Master of Restoration and Rehabilitation of Historic building and textiles, Shahid Beheshti University, Architecture and Urban \\ Planning Faculty, Tehran, Iran - avisafarzaneh20@gmail.com
}

Comission II - WG II/8

KEY WORDS: Coping with heat, Chahar- Sofe (Four-sided) house, Combined with Hot and Dry Climate, Zoroastrian Village of Mazraeh Kalantar.

\begin{abstract}
:
The body of every village like Mazraeh Kalantar village was formed based on geographical, economic and cultural factors. The geographic factor itself consists of two categories, namely artificial geography and natural geography. Many factors can be classified under the heading of natural geography. In the field of physical architecture, the focus is mostly on climate fact ors, such as water, wind, cold, heat, humidity, sunlight, shape and the substances of the land. The Zoroastrian Village of Mazraeh Kalantar is located in the Meybod city (Yazd, Iran) and a hot and dry area. There are Chahar-Sofe (four-sided) houses in this village and various methods and considerations have been proposed to prevent the sunlight in these houses; therefore, in this study, in order to find the solutions for coping with heat and Combined with dry and hot climate in Chahar- Sofe houses of the Mazraeh Kalantar village, five houses have been investigated. Some of these solutions include: selecting the right geographical location, creating sofe (porch), Creating shadows, choosing a suitable type, colour, and size for the building materials, choosing the right type of roof covering, central courtyard, having the suitable architectural body and mass for houses, etc. These items show how much environmental factors, especially the climate of a village, can affect every aspect of a house, including: the type of home materials, the physics and shape of the house, elements of the home, how the house is Geographic orientation and the spaces inside it, etc.
\end{abstract}

\section{INTRODUCTION}

The Mazraeh Kalantar village is a Zoroastrian village in Iran and "is located 11 kilometers southeast of Meybod in Yazd province. This village is located at a longitude of 54 degrees and 6 minutes and latitude 32 degrees and 12 minutes at an elevation of 1100 meters above sea level. "(Mazraeh kalantar village conductor plan. 2011).The year of the foundation of the village is around 250-300 years ago."(Shahmardan, 1957). The houses in this village mostly have the chahar-sofe plan consisting of chaharsofe (four porchs), 4 rooms in the corners and the middle space central courtyard.

The village is located in warm and dry climate. Which climatic features are as follows: High temperature and intense direct sunlight and High average sunny days per year (especially in summer day), Extreme temperature fluctuations in the village in winter and summer and at day and night, High evapotranspiration, especially in summer, The annual rainfall is very low and variable and irregular, There are warm winds and dusty winds for half a year. (Conductor Plan of Mazraeh Kalantar Village, 2011)

According to the climatic characteristics of the village, one of the most important features is the existence of excessive heat more than the range of thermal comfort. Therefore, this research is aimed at find indigenous solutions of the Mazraeh Kalantar village to harmony with the hot and dry climate to cope with the heat, Hence it considered the climatic parameters that are related to this issue including intense direct sunlight on the day especially in summer, severe temperature fluctuations throughout the day and the high temperature difference between night and day, very low humidity and dry air and how the villagers respond to these parameters, to create thermal comfort conditions and minimizing its adverse effects in the Chahar-sofe Houses of this village and how it affects the shape and form and structure of the village houses. That of the five Chahar-sofe Houses in the village, a case study was used to achieve the goals of this study.

Despite of numerous and varied researches about the ways for coping with heat in hot and dry climates in Iran; there have not been considerable studies on how these ways affect the body and shape of four-side houses.(Case study of the four-side houses of the Mazraeh Kalantar village). Since the author of this research is from this village, she could be able to understand it tangibly, consequently, the author explains the necessity of doing this research.

Research Methodology: To achieve the main purpose of this research, the five chahar-sofe (Four-sided) houses in the village are selected and studied and are compared to each other. The method of collecting information is field and documentation and libraries and this research is formulated with a descriptiveanalytical approach.

To enter research objectives, initially, the position of the five sample houses in the Present (2019) in the village are shown. Then briefly the available spaces in the Chahar- Sofe houses are discussed.

\footnotetext{
* Corresponding author
} 


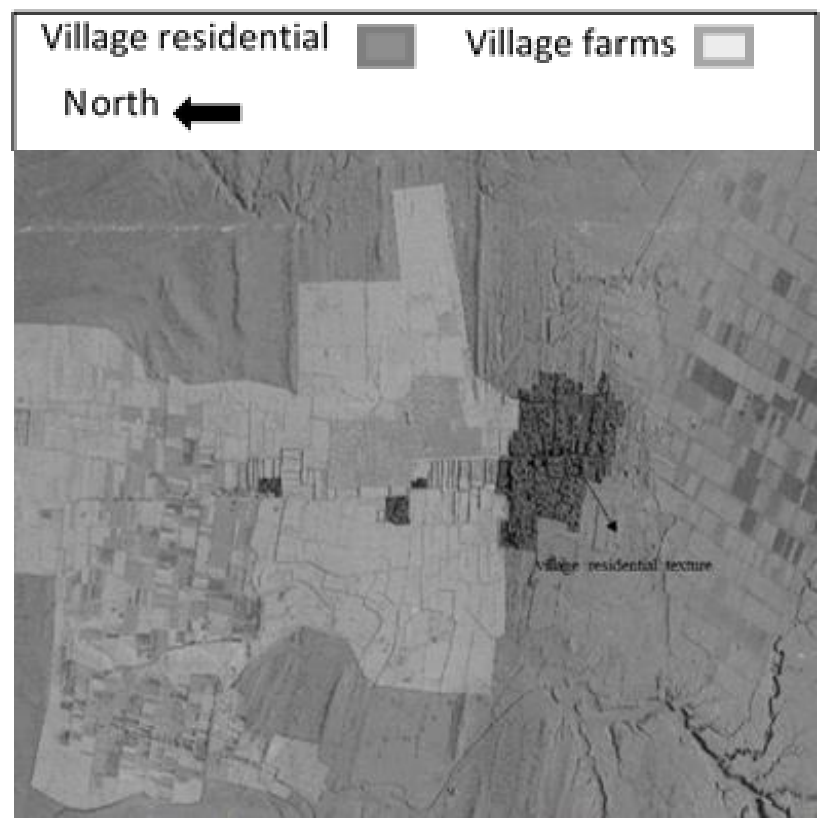

Figure 1. Village aerial photography, Compactness of residential living texture, Year of 1967.

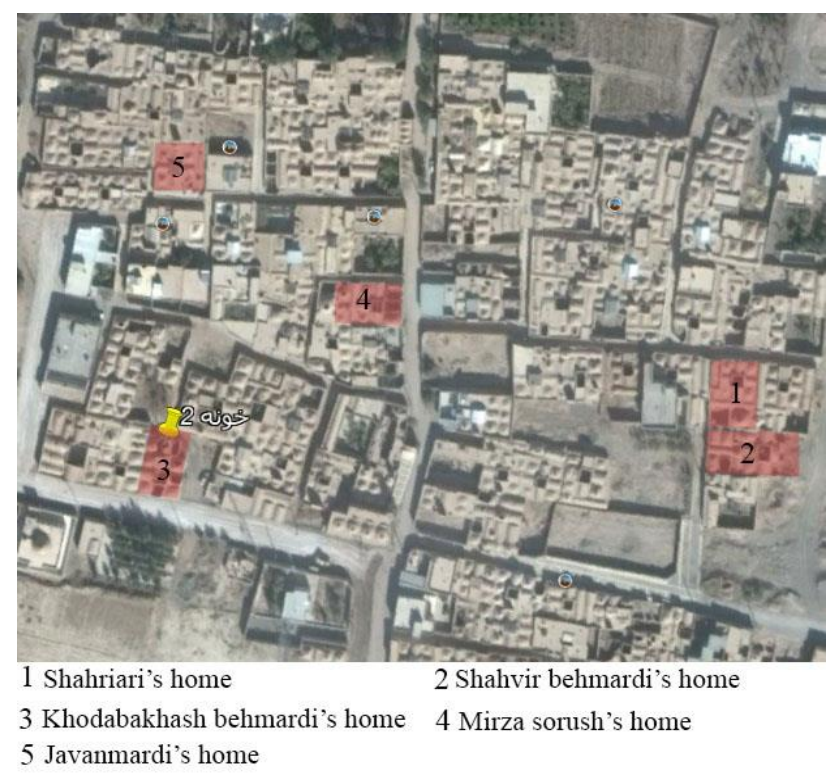

Figure 2. The position of the houses in the aerial photograph, year of 2019.

\section{HEAT RELATED CLIMATIC PARAMETERS AND SOLUTIONS FOR THE VILLAGERS TO CONFRONT IT IN THE CHAHAR-SOFEH HOUSES OF THE MAZRAEH KALANTAR VILLAGE}

\subsection{Intense and direct sunlight on the day especially in summer}

The best solution to responding this incompatibility is creating shadows in the context and village houses to prevent the direct permeation of light into the house and its spaces. Here are the solutions that the villagers have chosen to adapt their homes to this climatic parameter of the village and how it affects the physical shape and body of houses.
2.1.1 Type and volume of the building and its enclosure: "One of the way to prevent penetrating sunlight to the house and its spaces is enclosing the building in a closed fence and a controlled climate."(Ghobadian, 2014). The form of all the houses in the context of the Mazraeh Kalantar village, including five case study houses in this study are cube shaped and dense (Like the village context which is dense and compact). Because of its lowest surface resistance to direct sunlight. By examining the dimensions and area of the courtyards (S1) and the total area of the house (The total area of residential space + Entrance corridor: S2) of the case study houses in the village, the ratio of yard area to total area of the house is between $5 \%$ and $7.5 \%$. As a result, the central courtyard has little area to the whole house. (The Largest yard area: $30 \mathrm{~m}^{2}$ and The Smallest yard area: $11 \mathrm{~m}^{2}$ ).

On the other hand, the height of four sofe (porch) is greater than one in relation to the width and length of the yard in all the case studies. According to studies conducted on these five houses, it is as follows: $1.02 \leq \mathrm{h} / \mathrm{a} \leq 1.42$ and $1.05 \leq \mathrm{h} / \mathrm{b} \leq 1.72$. (h: The height of the sofe (porch), a: The length of the yard, b: The width of the yard). "The four sofe around the courtyard with its high elevation relative to the yard dimensions, emphasizes the small area of the yard and gave it a type of deep hole that came out of the cubic volume of the house."(Esfanjari Kenari, 2007). Due to the deep central courtyard, and safeguarding it by the four sofe, helps the yard shade and keep it cool during the day and breathe of the house. So it can be concluded that the proportion between the length and width of the central courtyard with the height of the sofe to what extent can be effective to cope with heat Mazraeh Kalantar village houses.

\begin{tabular}{|c|c|}
\hline \multicolumn{2}{|c|}{$\begin{array}{l}\text { Proportion between central courtyard area and whole house } \\
\text { area In these case study houses } \\
\text { (Central courtyard area:S1, The total area of the house: S2 ) }\end{array}$} \\
\hline $\begin{array}{c}\text { Home's } \\
\text { name }\end{array}$ & Plan \\
\hline $\begin{array}{l}\text { Shahvir } \\
\text { Behmardi's } \\
\text { home: The } \\
\text { largest ratio } \\
\text { between } \mathrm{S} 1 \\
\text { and } \mathrm{S} 2: \mathrm{S} 1 \text { / } \\
\mathrm{S} 2: 20 \mathrm{~m}^{2} / 270 \\
\mathrm{~m}^{2}: 0.075\end{array}$ & 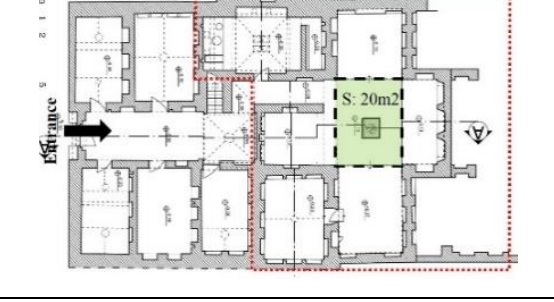 \\
\hline $\begin{array}{l}\text { Javnmardi's } \\
\text { hoeme : The } \\
\text { smallest ratio } \\
\text { between S1 } \\
\text { and S2: S1 } \\
/ \mathrm{S} 2: \\
11 \mathrm{~m}^{2} / 190 \mathrm{~m}^{2} \text { : } \\
0.05\end{array}$ & \\
\hline $\begin{array}{l}\text { Khodabakhsh } \\
\text { Behmardi's } \\
\text { home: } \\
\text { S1/S2: } \\
15.20 \mathrm{~m}^{2} \\
/ 225 \mathrm{~m}^{2} \quad: \\
0.067\end{array}$ & 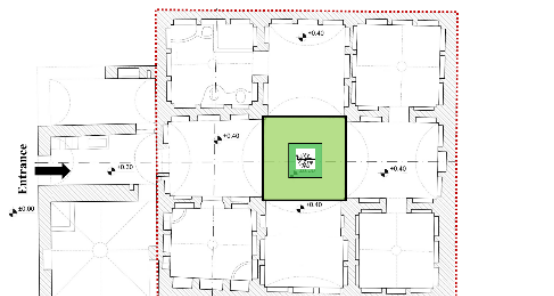 \\
\hline
\end{tabular}




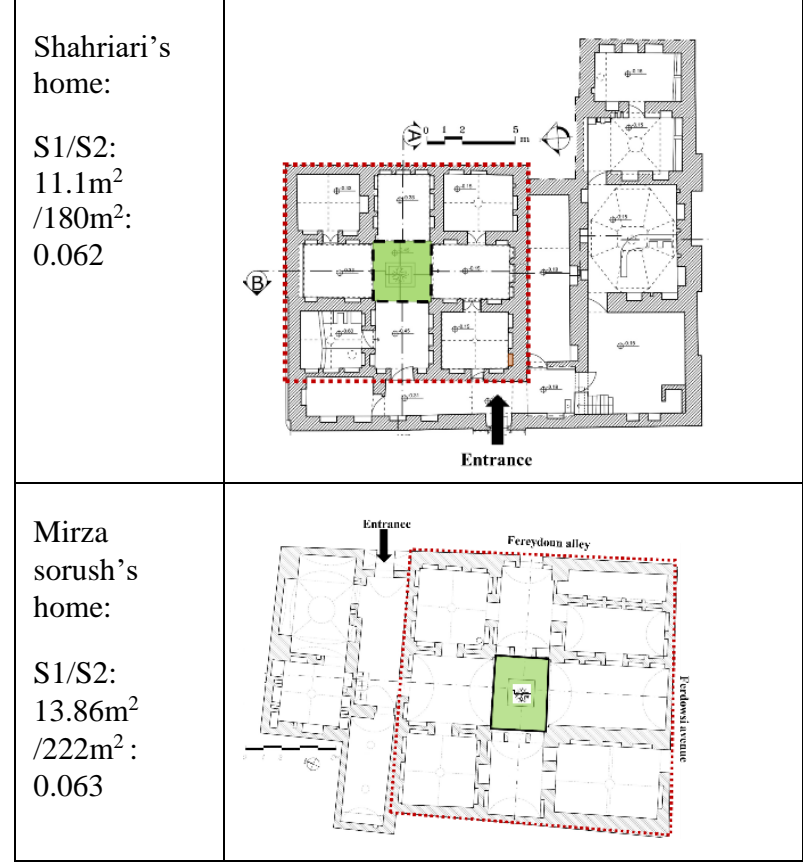

Table 1. Proportion between central courtyard area and whole house.

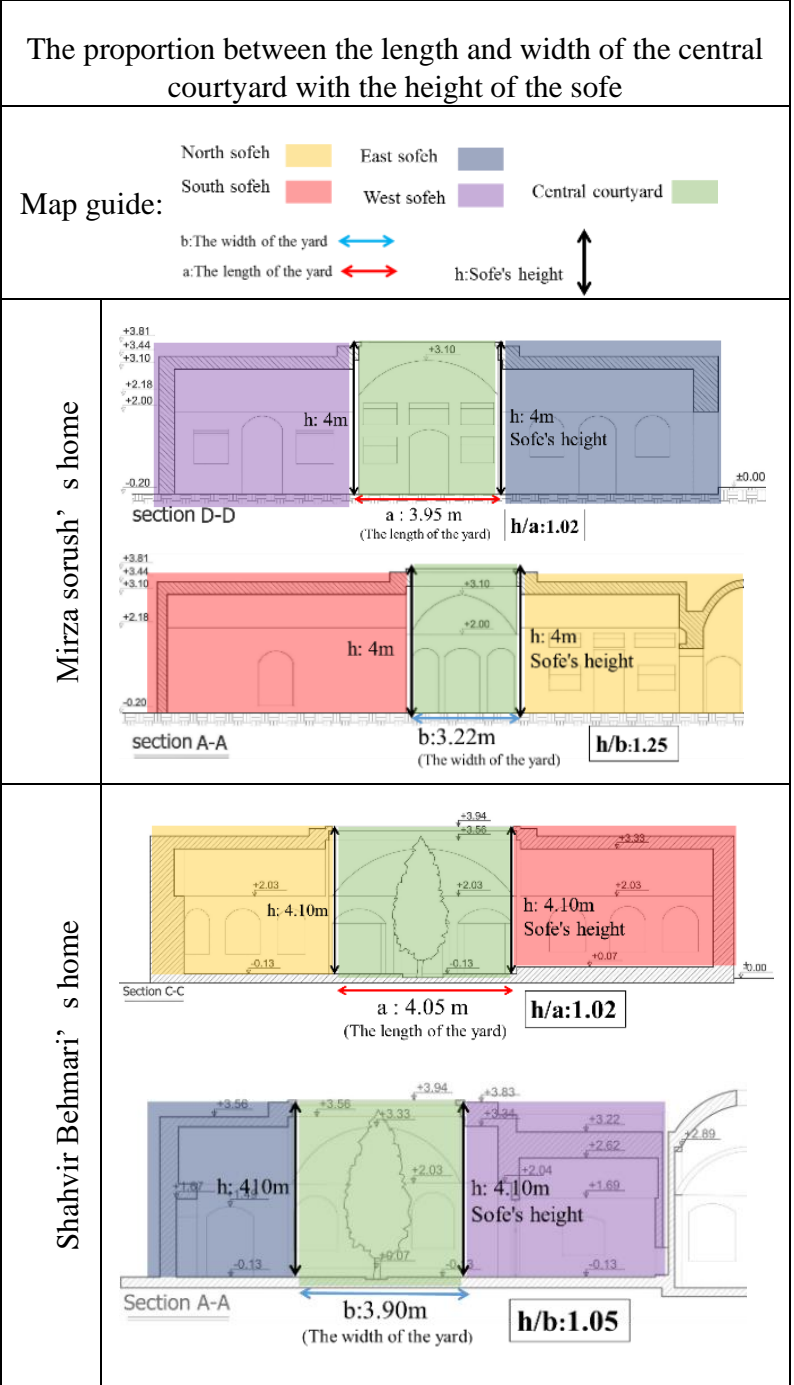

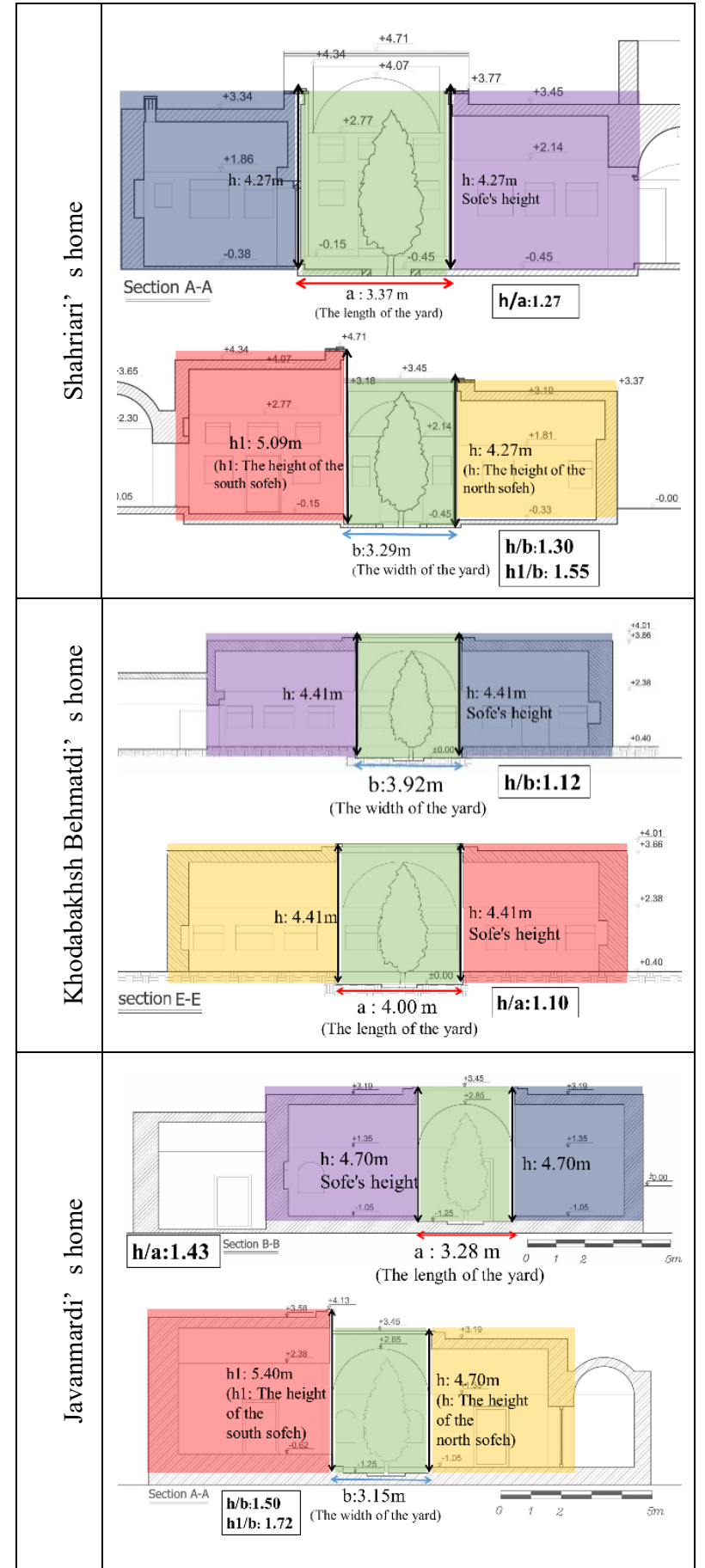

Table 2. The proportion between dimensions of central courtyard with the height of the sofe.

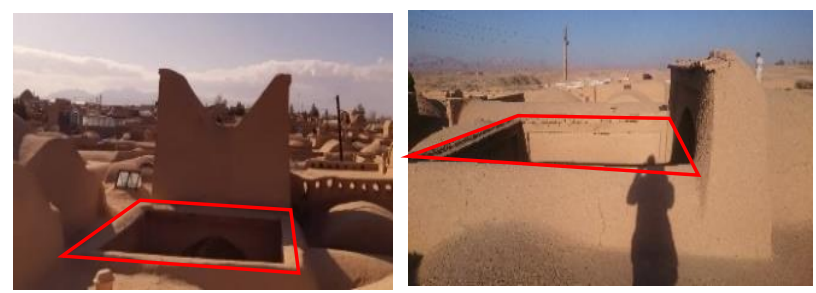

Figure 3. The central courtyard is like a deep hole in the middle of the house. 
2.1.2 Creating four porches (sofe) in the house: In the Mazraeh Kalantar village, the houses have four sofe in four directions around the central courtyard (That's why they are called chahar-sofe (Four-sided) houses. In all the houses in this study, the plan of the sofe is rectangular which its small side is in line with the yard and its large side is in the bottom of the sofe. The sofe is in front of the rooms and the entrance to the rooms is from the sofe.

In fact, the porches, which are deeper than their length. For example in the janmardi's home: The ratio of the depth of sofeh (y) to the width of sofe (x) in all corners of this house is greater than one $(y / x>1)$. By placing the sofe (porches) in front of the rooms, the sofe (porches) create the optimal shade in front of them on summer days, when the sun is vertical at noon. Since sunlight does not penetrate directly into the walls of the room, the interior of the room is cool throughout the day. "On the other hand, the porches shades on all four sides on the courtyard. It allows homeowners to use it throughout the day."(Tahbaz, 1995). In some houses of the Mazraeh Kalantar village like the Shahriari's house and Javanmardi's house (Two examples of case study houses) the southern porches are taller than the other porches. Due to its height, it also casts a shadow over the central courtyard. In addition; due to the orientation of this porch facing north and based on the sun's rotation during the day, this porch is back to the sun and shady during the day, In addition; the south sofe in all chahar-sofe homes in this village is the bigger than other sofe (According to their religious beliefs).

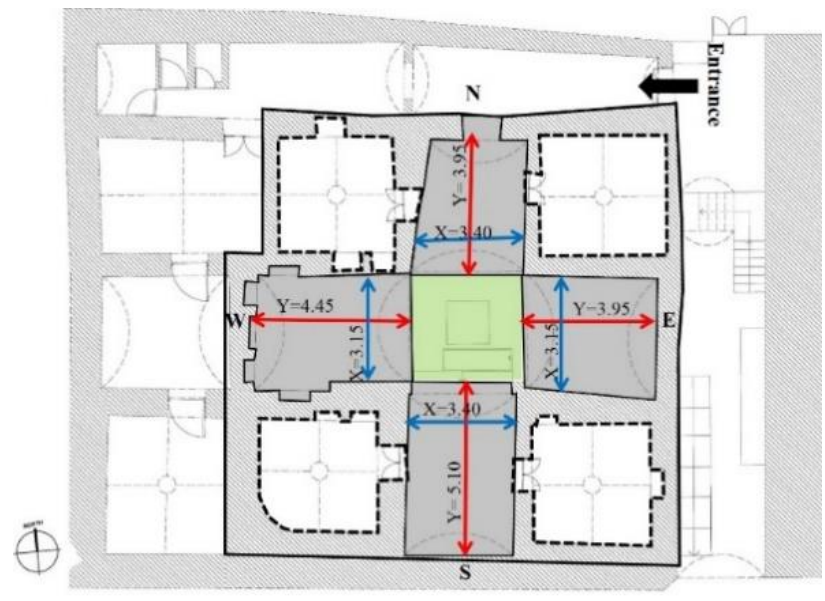

Figure 4 . The proportion the length and width of the sofe in the javanmardi's home.
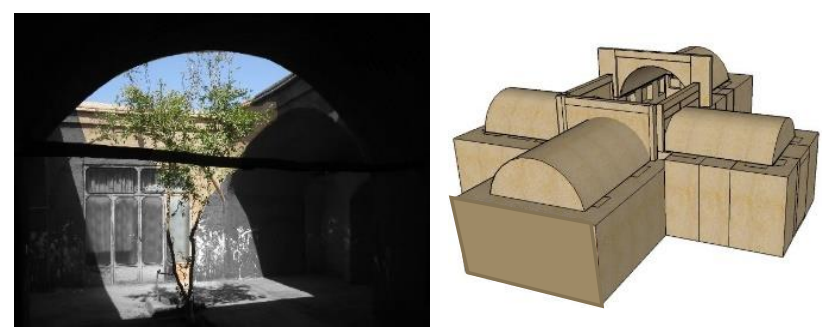

Figure 5. Shading by the sofe in the central courtyard and four numbers of sofe in the chahar-sofe house.

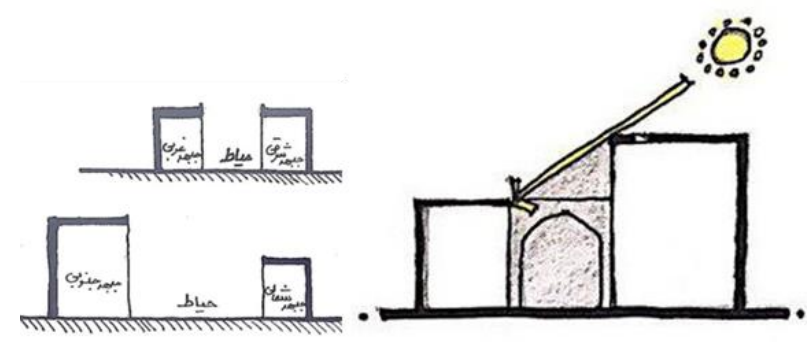

Figure 6 . The shade of the south sofeh overlooking the courtyard during the day.

2.1.3 Geographic orientation (based on sun rotation) the interiors of the chahar-sofe houses of village: Residents of the Mazraeh Kalantar village to protect their interiors homes from direct sunlight and heat during the day, especially in the summer, positioned the important house spaces in terms of sun orientation and rotation and the activity of homeowners is shaped by it. In fact, its central courtyard is surrounded by four porches, divides the house into four sections during the day (from morning to evening) and during the seasons according to the orientation and rotation of the sun. Each part of the building is dedicated to a part of the day or a season of the year.

North sofe: The northern sofe has diagonal sunshine and during the early hours of the day (from 6am to $11 \mathrm{am}$ ) especially in summer. In winter, it is exposed to diagonal sunlight almost all day long and since the depth of this sofe is less than the south one (East-West elongation), as a result, it receives relatively good sunlight and is the best location for home wintering, especially in the colder months of the year (December, January, February).

South sofe: The south sofe is behind the sun, which is called the "shady spot" and is in the shade at noon (12 noon to sunset) especially in summer. Often the basement of the house is also in this front of the building. "This wall in the hot months (June, July, August and mid-September) shows good performance in terms of being protected from direct sunlight". (Zarei, Mirdehghan, 2017) they are also called summer sofe.

East and West sofe: The depth of these two porches is almost equal. Eastern sofe facing west due to the sun's rotation, has less shade than the other porches. And it can only be used in the afternoon, around $4 \mathrm{pm}$ until sunset in the summer. The western sofe is used almost all day in all seasons.

\begin{tabular}{|c|c|}
\hline $\begin{array}{c}\text { Sun rotation of spaces } \\
\text { and their names in } \\
\text { four-sofe houses }\end{array}$ & $\begin{array}{c}\text { Images of the types of activities } \\
\text { inside the space }\end{array}$ \\
\hline North sofe &
\end{tabular}




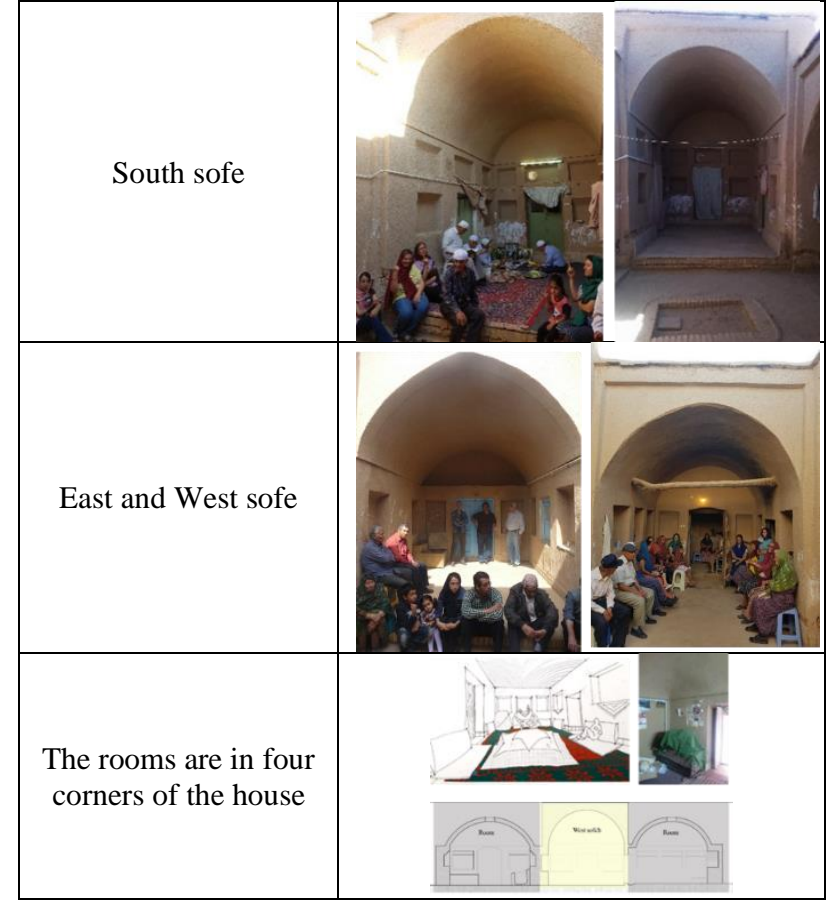

Table 3. The names of the home's spaces.

It should be noted that since the rooms of the house are not directly related to the yard and the porch is in front of the room. They are therefore exposed to indirect sunlight and shade. As a result, rooms can be used throughout the year and throughout the day. "As a result of the functionality of each of the home spaces according to the day, the month and the year, the response to the need is different depending on the time. And on the other hand, each of the residential areas of the home has a specific climatic function. And can have a different function. "(Ghezelbash, Abolzia, 1986).

Hours of shading of home spaces due to the sun's rotation on a summer day

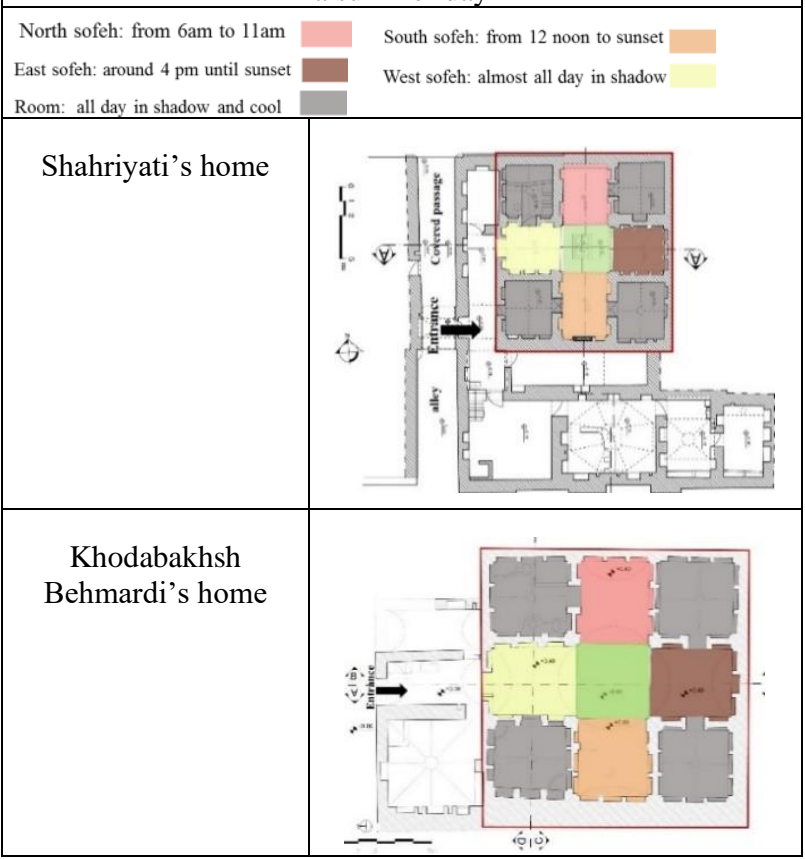

Table 4. Performance of home spaces due to sun circulation on a summer day.
2.1.4 Type of suitable roof for village houses: The type of roof covering of the rooms of the case study houses are often the dome and the roof of the sofe are vaulted and there is no flat roof (Excluding part of the roof that has been made flat to sleep).As a result, the roofs are curved and spherical. "Sunlight in summer is almost vertical but the arch and dome surface are inclined to the sun. Because of the curvature of the arch and dome surface, part of it is always overshadowed. This helps reduce heat absorption."(Ghobadian, 2014). As the hot air is lighter and goes up and the cool air replaces it, by installing a skylight, the warm air exits the skylight and there is a natural flow of air from the bottom to up, which is suitable for comfort in hot seasons. As a result, this form of roof creates shadows on the other part of the roof and reduced waste energy absorption and it also prevents it from being wasted at night.
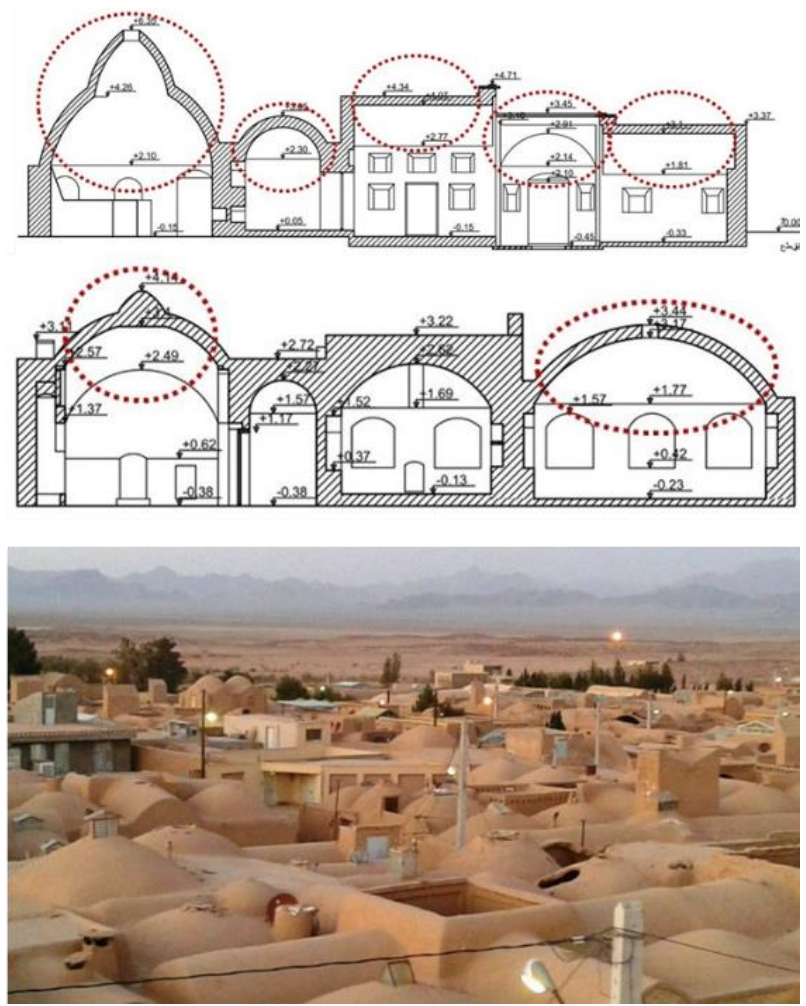

Figure 7. An example of a curved roof in the chahar-sofe houses.

2.1.5 Type and area of opening in village houses: Windows and openings play an important role in heat transfer. Generally the rooms of the houses in this village have no windows in the yard or outside in their walls and the lighting and ventilation of the rooms are provided by ceiling light. Inside the walls of the rooms except the entrance doors, which also open to the porches, they have no other opening. Because these rooms are sheltered by sofe (porch) and do not open directly to the yard and the outdoor environment, so they are not exposed to strong, direct sunlight. On the other hand, "In these houses, no windows open to outdoor and the only opendoor opening which is connected to the outside of the house is at the entrance which is connected to the central courtyard through the relatively long corridor and entrance sofe."(Ghobadian, 2014). 


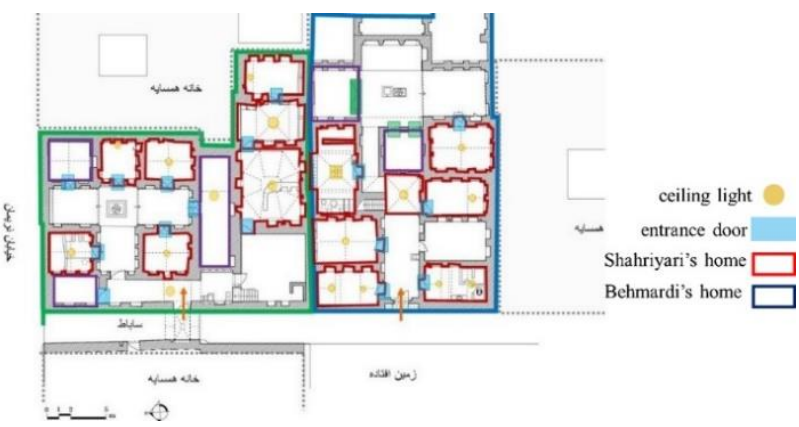

Figure 8: Tow houses for showing: Type and area of opening in the village houses.
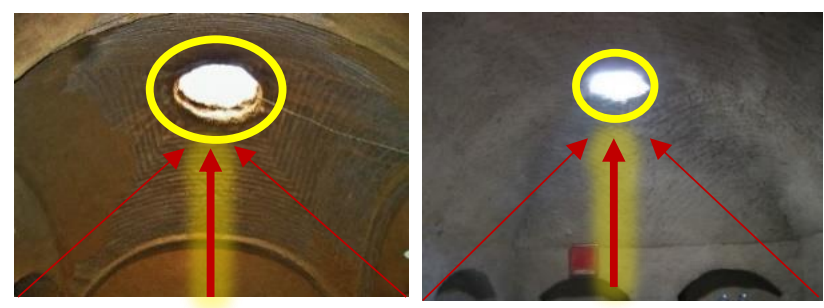

Figure 9. An examples of ceiling light in these houses.

2.2 Severe temperature fluctuations throughout the day and the high temperature difference between night and day:

One of the climatic features of the Mazraeh Kalantar village (hot and dry climate) is a sharp difference between daytime and night time temperatures and severe temperature fluctuations. "The best way to thwart thermal grade change is delaying as much heat permeation as possible inside the building so the stored heat of the walls or ceilings penetrates the building when is needed." (Rapoport, 2014).In the following the different ways that villagers have used in their homes to achieve this goal and how it affects the body of homes is presented.

2.2.1 Use of appropriate materials in homes: Most of the materials and mortars used to build the walls and ceiling of the village houses are the adobe with mortar of clay and use straw -clay as the exterior and interior finish of the home and the final layer of the roof. And the floors of the rooms and the yard were also crushed soil or use brick with plaster mortar. These materials are used in the houses, have a high heat capacity. Because they have a lot of mass and are made up of high-density, compact particles. These materials prevent heat from entering the room during the day, by absorbing heat throughout the day and storing it in themselves. When the air is cooler at night, these materials transfer the stored heat to the room, which increases the comfort of the person in the house.

2.2.2 Suitable dimensions of the structure (wall and roof thickness): Heat transfer or it prevention is also directly related to body thickness. That's why in this village the walls and even the roofs of houses are often of considerable thickness to ensure that heat is not penetrated. The thickness of the bearing walls in these houses is often between 60 and $70 \mathrm{~cm}$, even this thickness reaches $80 \mathrm{~cm}$.
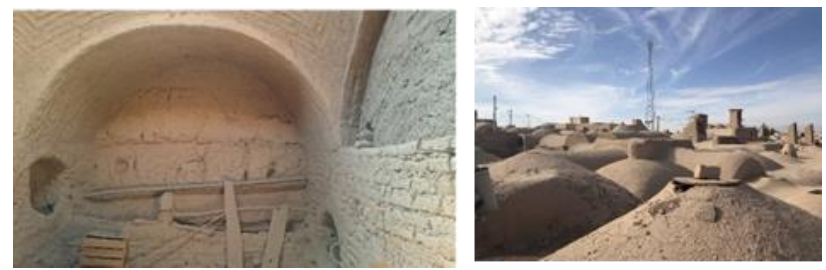

Figure 10. The material of adobe and straw-clay in these houses.
Thickness of roof covering and roofing layers: 1. Vaulted or dome is created with adobe with mortar of clay $(22 \mathrm{~cm}), 2$. Plaster slurry $(2 \mathrm{~cm}), 3$. Ghure Gel (A special type of mud for roof insulation: $8 \mathrm{~cm}), 4$. Straw-clay $(2 \mathrm{~cm})$. The thickness of these roofing layers plus the thickness of the main roof covering is generally between 30 and $40 \mathrm{~cm}$.

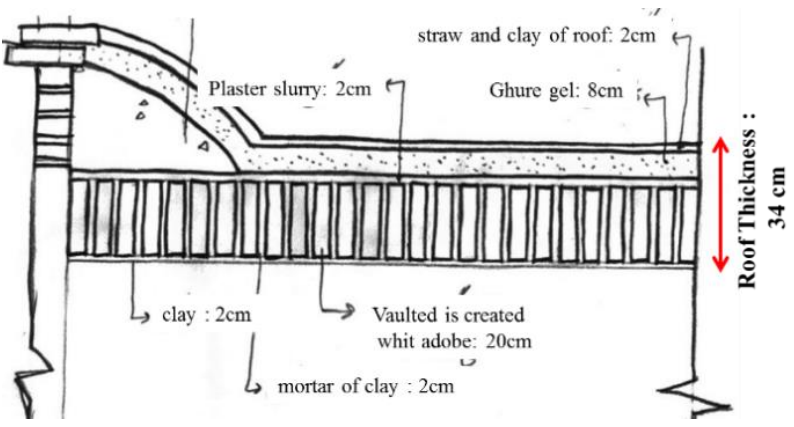

Figure 11. Thickness of roof covering and roofing layers.

\subsubsection{Colour of appropriate materials in village houses:} The colour of objects, including buildings, is directly related to the absorption and excretion of heat and cold. In the case study houses in the village, there is a straw-clay overlay on the walls as well as on the roofs. The bright, peachy colour of the straw-clay increases the reflection of light and heat externally and reduces their absorption into the home.

2.2.4 Architecture on the in the soil shelter: In the Mazraeh Kalantar village, the villagers to deal with the overwhelming moments of summer midday take refuge in the soil. As a result, some village houses such as one of the case study houses has a basement. The level of the case study houses and also the level of the courtyards is lower than the natural level of the alley ground. Because the absorption and storage capacity and heat transfer capacity of soil is unlimited (Soil is as thermal capacitor) and the basement of the house from any space on the ground will be cooler). As a result of the gradual absorption of heat and cold in the soil, it has depreciated the daily and yearly fluctuations and moderates the temperature. On the other hand, in the basement, ground adjacent to building walls as external thermal mass to reduce heat exchange is used to keep the indoor air temperature constant that reduces heat transfer from the inside to the outside and vice versa. So it can provide thermal comfort inside the basement in hot summer weather by this way.

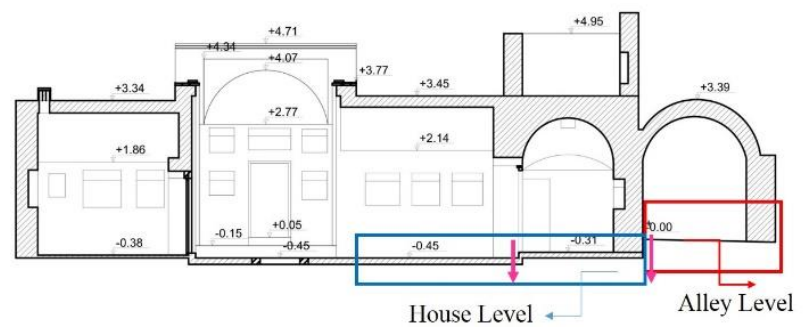

Figure 12. The lower house level than the alley level

\subsection{Very low humidity and dry air}

Since one of the climatic features of the Mazraeh Kalantar village is low relative humidity and dry air and high evaporation during the day, so the possibility of cooling the air and using cooling air at night and also the wind with humidity that burns from the north, is one of the ways of coping with heat in this climate in village houses. In the following the solutions of the villagers is offered for increasing humidity and use of cool air and wind in the chahar-sofe houses of the village. 
2.3.1 Creating the small climate using the central courtyard pattern in village houses: In the village houses, including the case studies, is a garden with a cedar or pomegranate inside it. This increases the relative humidity in the living space of the building and increases the softness of the air by shading. As a result, the yard becomes a source of coolness and with a decrease in the degree of warmth and to prevent the reflection of heat absorbed by the yard floor and the evaporation of water, change the small climate of the home completely and it provides thermal comfort to people in the home.
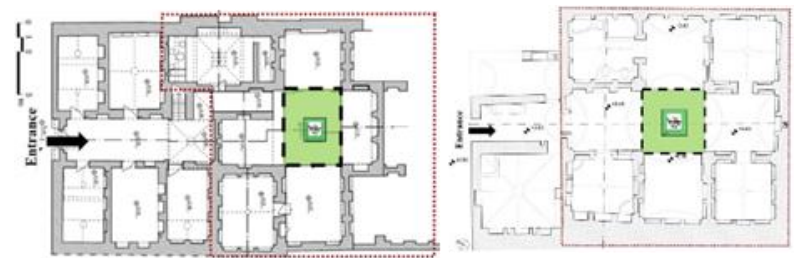

Figure 13. Create a garden in the central courtyard of the house.
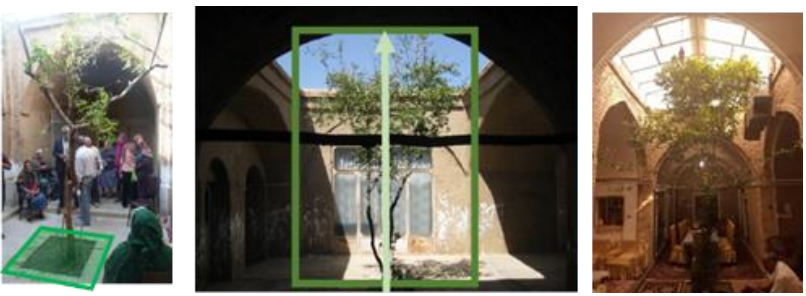

Figure 14. The examples of the trees and the garden in the homes.

2.3.2 Wind catcher mansion (The taller south sofe): Sofe Southern (Longer porch) of Shahriari's House (one of the case study houses) because of being taller than other porches (sofe) of the house, has a Wind catcher-like function. This is called the Wind catcher mansion. Of course, this property works in conjunction with the small courtyard. (The height of the Ivan is 1.4 to 1.7 times the length of the small yard.) So in most of the day, the Ivan's heavy shadow wide over the yard. The yard during the night settles down the desert's cool air. "During the hot summer days sofe also keeps the air cool. This south sofe facing north absorb the cool, humid wind blowing from the north and take it down. This airflow drives all the yard and sofe air. The warm air that accumulates in the space near the ceiling of the porch is driven by the wind through a hole in the soffit spray at its highest point (near the arc tip) and driven out." (Esfanjari Kenari, 2007).

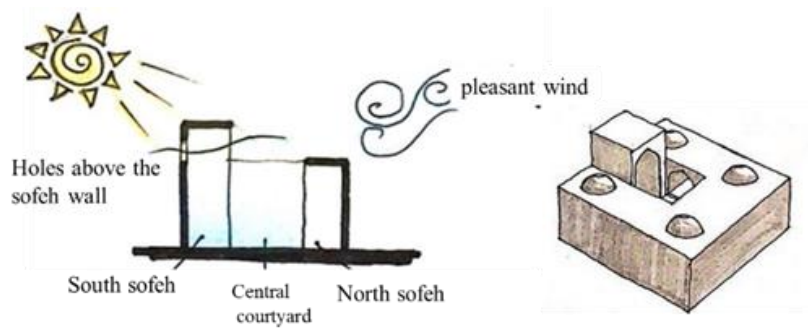

Figure 15. Function of the South sofe as a Wind catcher mansion.
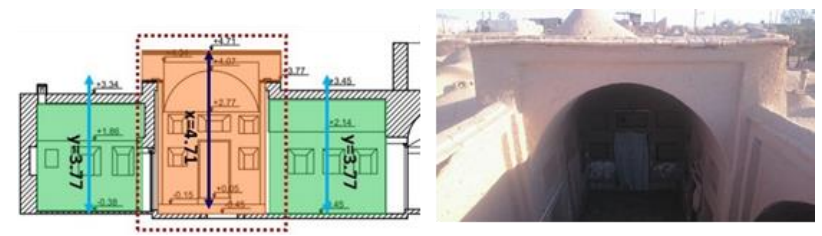

Figure 16. South Side higher than other sides in the Shariari's home.
2.3.3 Use porches (sofe) and roofs at night, especially in summer: One of the ways to enjoy the cool of the night and the wind in the village, the use of the radiant heat of the earth's night heat into the clear, cold night sky of the village. For this purpose the porches (sofe) that were often in the shade during the day also use some of the roofs that they have been flat for summer activity and sleep. Of course during the day also depending on the clock and the sun's circulation for daily activities like religious ceremonies. . "This is with the accumulation of confined air and the soil in the hollow parts of the curved roof, is a good insulator to prevent heat from penetrating and to delay its permeation as much as possible. " (Tahbaz, 1995).

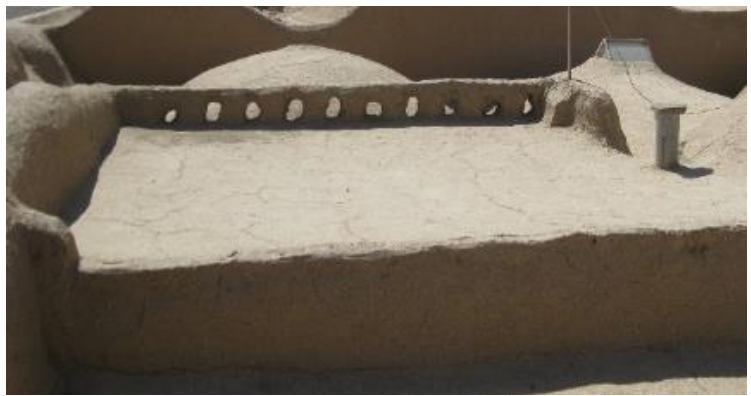

Figure 17. The roof flat for sleeping in summer nights.

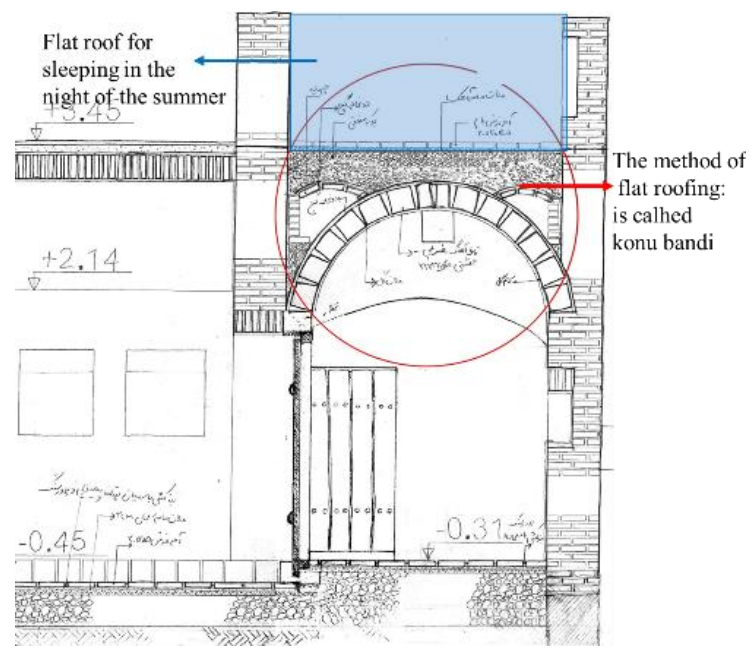

Figure 18. The flat roof and the method of flat roofing.

\section{CONCLUSIONS}

According to this research, "in architecture, the theory of cause-andeffect relationships between climate and shape of a building (a house) emphasizes that the most important or first concern of human is to shelter himself, as a result climatic factors determine shape of a building. In order to reach comfort (comfort point), these factors must be approached in such a way as to create a certain degree of equilibrium between these factors and the environmental stimuli. Therefore, a building should respond to heat and reflect the heat absorbed by the earth and air, etc. So, different parts of a building can be considered as a tool to control the environment. "(Rapoport, 2014). Combating with hot and dry climate to counteract heat in Mazrae Kalantar village encompasses the whole house, including the orientation and placement of house spaces, the type of roofing and lighting, the colour and type of materials, etc. Here's how heat resistance impacts all the elements of Chahar-sofe houses. These houses have also responded to climatic factors against the heat, and the villagers have implemented solutions in their houses in the regard which is summarized in the table below. 


\begin{tabular}{|c|c|c|}
\hline $\begin{array}{c}\text { Reasons and } \\
\text { climatic features } \\
\text { of a climate } \\
\text { affecting the } \\
\text { formation of } \\
\text { spaces } \\
\end{array}$ & \multicolumn{2}{|c|}{$\begin{array}{l}\text { Impact on the Chahar-sofe (Four-sided) } \\
\text { houses of the Mazraeh kalantar Village }\end{array}$} \\
\hline \multirow{5}{*}{$\begin{array}{l}\text { Counteracting } \\
\text { the intense } \\
\text { direct sunlight } \\
\text { of the day, } \\
\text { especially in } \\
\text { summer }\end{array}$} & \multirow{4}{*}{$\begin{array}{l}\text { Shadowing at } \\
\text { home }\end{array}$} & $\begin{array}{c}\text { Enclosed and } \\
\text { introverted } \\
\text { architecture with } \\
\text { central courtyard } \\
\text { pattern }\end{array}$ \\
\hline & & $\begin{array}{l}\text { Creating an sofe(four } \\
\text { sofe around the yard) } \\
\text { with great depth in } \\
\text { front of the rooms) }\end{array}$ \\
\hline & & $\begin{array}{l}\text { Dividing the house } \\
\text { into four parts per } \\
\text { day based on the } \\
\text { direction of the sun's } \\
\text { rotation to take } \\
\text { advantage of the } \\
\text { shade during the day: } \\
\text { daily and seasonal } \\
\text { horizontal migration } \\
\text { in the four parts of } \\
\text { the house }\end{array}$ \\
\hline & & $\begin{array}{l}\text { Curved and spherical } \\
\text { ceiling of home spaces } \\
\text { (vault and dome) }\end{array}$ \\
\hline & \multicolumn{2}{|c|}{$\begin{array}{l}\text { Minimum openings in rooms (ceiling } \\
\text { lights and entrance doors) }\end{array}$} \\
\hline \multirow{4}{*}{$\begin{array}{l}\text { Coping with } \\
\text { severe } \\
\text { temperature } \\
\text { fluctuations } \\
\text { during the day } \\
\text { and seasons of } \\
\text { the year }\end{array}$} & \multirow{4}{*}{$\begin{array}{l}\text { Delaying heat } \\
\text { penetration into } \\
\text { the building: } \\
\text { increasing the } \\
\text { heat capacity of } \\
\text { the materials and } \\
\text { creating a } \\
\text { thermal } \\
\text { capacitor }\end{array}$} & $\begin{array}{c}\text { Adobe materials } \\
\text { with mud and thatch } \\
\text { on walls and roof } \\
\text { covering of house } \\
\text { spaces }\end{array}$ \\
\hline & & $\begin{array}{l}\text { Thick walls and } \\
\text { ceilings }\end{array}$ \\
\hline & & $\begin{array}{l}\text { Creating a basement } \\
\text { (architecture in the } \\
\text { shelter of the soil) } \\
\text { and lowering the } \\
\text { level of the house } \\
\text { from the ground level }\end{array}$ \\
\hline & & $\begin{array}{l}\text { Bright and beige } \\
\text { colour of adobe and } \\
\text { thatch }\end{array}$ \\
\hline \multirow{3}{*}{$\begin{array}{l}\text { Coping with } \\
\text { very low } \\
\text { humidity and } \\
\text { dry air }\end{array}$} & \multirow{3}{*}{$\begin{array}{l}\text { Increasing the } \\
\text { humidity in the } \\
\text { house by } \\
\text { creating small } \\
\text { climates and } \\
\text { using favorable } \\
\text { wind and cool } \\
\text { night air in hot } \\
\text { days of the year }\end{array}$} & $\begin{array}{l}\text { Making a garden by } \\
\text { planting trees such as } \\
\text { cedar or } \\
\text { pomegranate in the } \\
\text { central courtyard }\end{array}$ \\
\hline & & $\begin{array}{l}\text { Creating a wind } \\
\text { catcher (taller } \\
\text { southern sofe) for } \\
\text { optimum wind use } \\
\text { (north wind with } \\
\text { humidity) }\end{array}$ \\
\hline & & $\begin{array}{l}\text { Using roofs and sofe } \\
\text { at night, especially on } \\
\text { hot days of the year }\end{array}$ \\
\hline
\end{tabular}

Table 5. How to Cope with Heat and Combined with Hot and Dry Climate in Chahar- Sofe Houses of the Zoroastrian Village of Mazrae Kalantar.

\section{REFERENCES}

Arab, M., Farokhzad, M., 2017. Design of Tent Buildings Based on Sustainable Architecture Principles to Reduce Building Energy Consumption in Hot and Dry Climates: Case Study of Shahrood City. Journal of Energy Policy and Planning Research, 8:147- 173 .

Esfanhari Kenari, E., 2007. Meybod That Is a City. Tehran: The Organization of the cultural heritage and tourism.

Farzaneh, A., 2017. Restoring and Reviving a Collection of Chahar-Soffeh Houses in the Mazraeh Kalantar an Approach to Preserving the Zoroastrian Existing Customs. M.A. Thesis. Shahid Beheshti University, Iran.

Ghezelbash, M., Abolzia, F., 1986. Yazd Traditional House Alphabet. Tehran: Ministry of Planning and Budget.

Ghobadian, V., 2014. Climatic Study of Traditional Iranian Buildings. Tehran: University of Tehran Publications.

Jodakia Azizi, A., Mousavi Haji, R., 2014. Chahar-sofe Pattern Typology at Iranian Architecture and its Evolution. Scientific Journal of Islamic Architectural Studies, 2: 64-88.

Kasmaie, M., 2014. Climate and architecture. Tehran: Soil Publications.

Shahmardan, R., 1966. Zoroastrian Worship. Bombay: Zoroastrian Youth Organization Bombay.

Mazraeh kalantar village conductor plan. 2011. Yazd Islamic Revolution Housing Foundation.

Mohamadi, A., 2011. Investigating and Explaining the Pattern of the Iranian House Based on the Pattern of Chahar-Soffeh. MA. Thesis. Yazd University, Iran.

Navai, K., Hajighasemi, K., 2011. Adobe and Imagination. Tehran: Soroush Publishing.

Rapoport, A., 2014. Pour une anthropologie de Ia maison. Afzalian, Khosrow. Mashhad: Kasra Library.

Rayegani, Ebrahim and Eslami, Masud. 2017. Investigating the Impact of Natural Factors on the Formation and Sustainability of the Historical City of Dehdasht. Quarterly Journal of Iranian Islamic studies, 31:51- 62 .

Thbaz, M., 1995. The basics of a desert architecture. Sofeh, 19:79- 89 .

Zarei, M. E., Mirdehghan, S. F., 2017. The Role of the Central Yard Pattern in Adjusting the Hard and Dry Climate Conditions, Yazd Region. Quarterly Journal of Iranian Islamic studies, 23:518 